\title{
DIE OPLEIDING VAN BEDRYFSIELKUNDIGES \\ AAN DIE UNIVERSITEIT VAN FORT HARE
}

\section{W. BOTHA}

\section{DEPARTEMENT BEDRYFSIELKUNDE UNIVERSITEIT VAN FORT HARE}

Die Departement Bedryfsielkunde aan die Universiteit van Fort Hare is 'n relatiewe jong departement en het eers in 1965 tot stand gekom. Voor hierdie datum is Bedryfsielkunde as 'n kort kursus deur die departement van suiwer Sielkunde aangebied en een van die destydse dosente, Dr. W. Backer, het die inisiatief geneem om 'n selfstandige departement van Bedryfsielkunde in die Fakulteit van Ekonomiese Wetenskappe op die been te bring.

Ofskoon die nuwe departement se groei aanvanklik stadig was, het studentebelangstelling toegeneem sodat daar vandag meer as 200 studente in hierdie vakrigting onderrig ontvang. Die groei van studentegetalle word in die tabel hieronder weergegee:

\begin{tabular}{cccccc}
\hline JAAR & 1 & 2 & 3 & NAGRAADS & TOTAAL \\
\hline 1965 & 7 & - & - & - & 7 \\
1966 & 1 & 2 & - & - & 3 \\
1967 & 5 & 3 & - & - & 8 \\
1968 & 4 & 4 & 3 & - & 11 \\
1969 & 6 & 2 & 2 & - & 10 \\
1970 & 18 & 2 & 1 & - & 21 \\
1971 & 22 & 8 & 2 & - & 32 \\
1972 & 54 & 15 & 5 & - & 74 \\
1973 & 50 & 21 & 5 & 1 & 77 \\
1974 & 77 & 12 & 4 & 2 & 95 \\
1975 & 72 & 34 & 10 & 4 & 120 \\
1976 & 120 & 42 & 29 & 5 & 196 \\
1977 & 141 & 34 & 25 & 5 & 205 \\
\hline
\end{tabular}

Dit blyk duidelik dat daar oor die laaste paar jaar 'n besondere groei in studentegetalle plaasgevind het. Die redes hiervoor is velerlei, maar die belangrikste is seker die besondere groot aanvraag wat daar in die bedryf bestaan vir opgeleide Swart bedryfsielkundiges. Hiermee tesame gaan die feit dat opgeleide Swart studente besondere hoë aanvangsalarisse ontvang in verhouding met Swart gegradueerdes wat in ander rigtings gespesialiseer is. 
Studente aan die Universiteit van Fort Hare kan Bedryfsielkunde as 'n vakrigting in twee graadkursusse in die Fakulteit Ekonomiese Wetenskappe volg. Die grade B.Com. en B.Admin. kan albei met Bedryfsielkunde as hoofvak gevolg word en studente kan nagraads tot op Doktorale vlak vorder. Sedert 1976 het 'n verdere graadkursus, B.A. (Personeelbestuur) tot stand gekom met Bedryfsielkunde en Industriële Sosiologie as hoofvakke. Hierdie graad maak veral voorsiening vir die opleiding van studente as spesialiste in menseverhoudings, met klem op verhoudings tussen Blanke en Swart werkers in die bedryf. Soos blyk uit die tabel het die byvoeging van hierdie graadkursus 'n besondere verhoging in studentegetalle teweeggebring en daar is tans ongeveer 30 studente wat die kursus volg.

Die belangstelling in Bedryfsielkunde word verder by Fort Hare gestimuleer deur die feit dat ' $n$ groot aantal beurse vir voor- en nagraadse studie aan die studente beskikbaar is. Hierbenewens word gevind dat talle studente deur ondernemings universiteit toe gestuur word met die doel om in personeelbestuur opgelei te word. Hierdie neiging het tot gevolg dat baie studente reeds 'n mate van ondervinding veral in personeeldepartement opdoen, voordat hulle die kursus kom volg. Studente is derhalwe meer onderleg in die beginsels wat bestudeer word. Daar is ook meer studentedeelname, veral op grond van persoonlike ondervinding van personeel- en ander bestuursprobleme en dit het gewoonlik lewendige besprekings tussen studente en dosente tot gevolg. Benewens finansiële hulp aan die studente deur ondernemings is daar ook hewige mededinging tussen werkgewers om senior studente te werf vir personeelbestuurs-, opleidings- en mensverhoudingsposte in hul onderskeie ondernemings. Baie min senior studente het nie reeds betrekkings voordat die finale eksamen afgelê word nie.

Die personeelsterkte van die departement het saam met studentegetalle gegroei en tans is daar 'n professoraat, senior lektoraat en lektoraat wat almal deur Blanke personeel beman word. Hierbenewens is daar ook 'n navorsings-assistentpos wat deur 'n Swart vrou beklee word, asook verskeie studente-assistentskappe. Dit is die beleid van die Universiteit van Fort Hare om, waar moontlik, Swart personeel wat oor die nodige akademiese en ander kwalifikasies beskik, voorkeur te gee wanneer betrekkings gevul word. Baie min Swart persone is beskikbaar wat oor hierdie kwalifikasies beskik en die Departement Bedryfsielkunde, soos ander departemente van hierdie universiteit, beywer hom om Swart personeel op te lei wat hierdie poste sal kan beklee. Die probleem bestaan egter dat gegradueerde studente met Bedryfsielkunde as hoofvak baie beter aanvangsalarisse in die bedryf kan bekom en aangesien die vraag na hierdie studente baie groot is, kan daar tot dusver nie 
suksesvol uitvoering gegee word aan hierdie beleid nie. Twee Swart lektore het in die verlede reeds poste in die departement beklee, maar die een het 'n hoër pos aan 'n ander Swart universiteit aanvaar en die ander is tans in die V.S.A. besig met nagraadse studie, waarna hy by die nuwe Universiteit van die Republiek van die Transkei 'n pos sal aanvaar.

Die huidige personeel van die Departement Bedryfsielkunde aan die Universiteit van Fort Hare huldig die opinie dat die studie-inhoud wat in die verskillende kursusse aangebied word, moet aanpas by die besondere omstandighede en vereistes van die Swart bedryfsielkundige. Derhalwe val die klem moontlik meer op sekere studieterreine as wat gewoonlik by Blanke universiteite aangetref word. Die beleid van die Departement in hierdie verband is geskoei op die besondere tipe student wat deur die bedryf benodig word en voortdurende kontak word met die bedryf behou om met redelike sekerheid te kan bepaal wat die vereistes van die bedryf is. Hierdie stelling moet egter nie die gedagte laat ontstaan dat kursusinhoud en studierigtings beperk is tot slegs die voorbereiding van streng gespesialiseerde graduandi nie. Die filosofie word aanvaar dat universiteite veral teoretiese kennis moet aanbied, maar hiermee saam word erken dat Bedryfsielkunde 'n gespesialiseerde studierigting is en dat praktiese onderwerpe 'n groot deel van die studie-inhoud moet uitmaak. Die beleid van hierdie Departement is om die wydste moontlike kursusinhoud aan te bied, maar in die meer gevorderde kursusse te spesialiseer in daardie rigtings wat spesifiek betrekking het op die tipe poste wat merendeels deur hierdie studente in die bedryf betrek word. Dit kom derhalwe daarop neer dat Swart bedryfsielkundiges veral in die volgende drie tipes poste gebruik word: Eerstens algemene personeelbestuursposte, tweedens opleidings- en veiligheidsbeampteposte en derdens spesialiste in mense- en rasseverhoudingsposte. Die kursusse wat aangebied word, het dus eerstens ten doel om goed afgeronde bedryfsielkundiges te produseer en tweedens om studente spesifiek in die drie genoemde terreine te onderrig. Die kursusinhoud kan as volg saamgevat word:

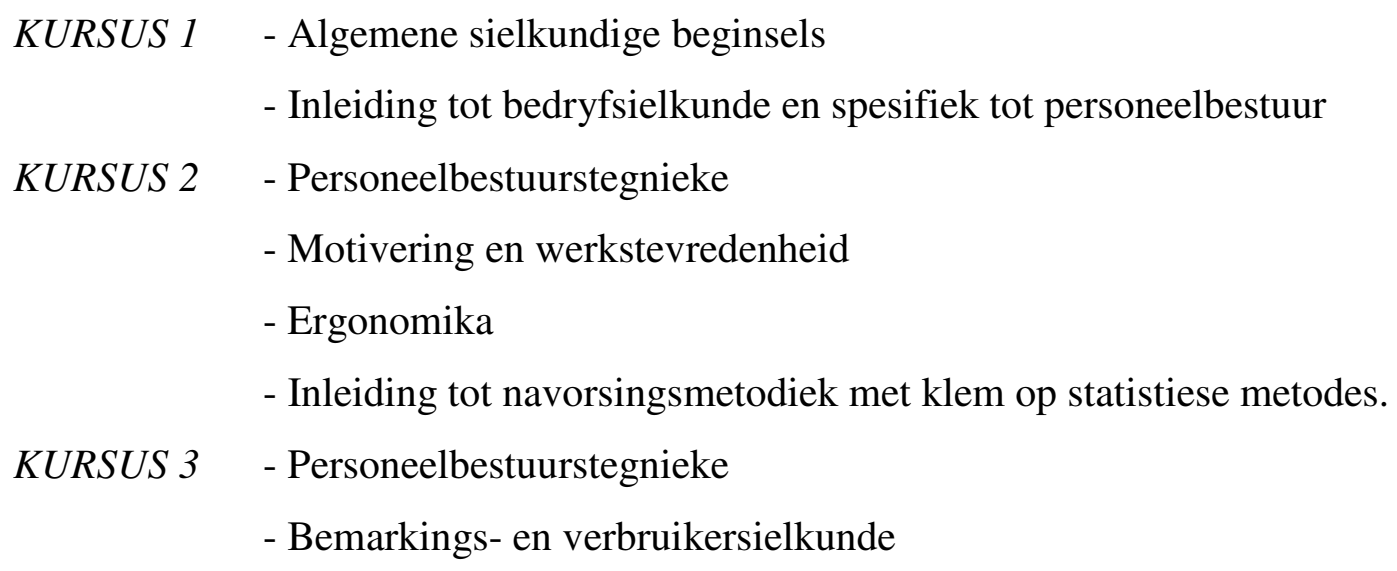


- Industriële psigopatologie en geestesgesondheid

- Groepsdinamika

- Sosiale en organisatoriese sielkunde

- Navorsingsmetodiek met klem op toetskonstruksie

\section{HONNEURS - Personeelbestuur \\ - Ergnomika \\ - Bemarkings- en verbruikersielkunde \\ - Sosiale sielkunde \\ - Navorsingsmetodiek}

Deurgaans word klem gelê op die rol van die Swart personeelspesialis in die toepassing van die verskeie bedryfsielkundige tegnieke en konsepte. En hoewel die onderskeie kursusse grotendeels onder dieselfde subhoofde as by ander universiteite aangebied word, val die klem miskien meer op die onderrig van studente in die drie genoemde terreine.

Een terrein waaroor die Departement 'n spesifieke opinie het, is die van die opleiding van mense- en rasseverhoudingspesialiste. Die Swart personeelspesialis word in hierdie terrein as 'n sleutelfiguur gesien. Een van die belangrikste probleme waarmee Suid-Afrika tans te kampe het, is juis rasseverhoudings. Die mening word gehuldig dat die werksituasie een van die beste is om 'n verbetering in rasseverhoudings teweeg te bring. Die rede is dat klein, beheerbare groepe teenwoordig is en ook omdat die grootste kontak tussen Wit en Swart hier plaasvind. Dit is ook waar dat die meeste rassewrywing hier voorkom en die Swart personeelspesialis is moontlik die beste persoon om 'n aktiewe en waardevolle bydrae te lewer om wrywing te voorkom en op te los. Om hierdie rede word daar gevoel dat Swart bedryfsielkundiges ' $n$ besondere rol kan vervul, veral omdat Swart persone die onderliggende houdings, kultuur en gevoelens van die Swart werker kan begryp en ook goed met die Blanke bestuur op hoë vlak kan kommunikeer ten opsigte van werker- en rasseverhoudings. Opleiding is dus daarop ingestel om Swart studente te onderrig in menseverhoudings, rasseverhoudings-opleidingstegnieke en ook die aard van die rol wat hulle sal moet vervul. Die instelling van die graadkursus, B.A. (Personeelbestuur) is daarop gemik om juis in hierdie behoefte te voorsien.

Die werksaamhede van die Departement Bedryfsielkunde is nie slegs beperk tot die formele en teoretiese onderrig van studente nie, maar verskeie ander aktiwiteite word ook deur die personeel en studente onderneem. Die belangrikste by-aktiwiteite is die aanbieding 
van praktiese kursusse aan alle voorgraadse studente. Daar word met hierdie onderneming gepoog om die praktiese toepassing van veral die personeelbestuurstegnieke en navorsingsmetodes te illustreer en aan die studente die geleentheid te bied om in die laboratoriumsituasie, eerstehands hiermee kennis te maak. Die inhoud van die praktiese kursusse is as volg:

KURSUS 1 - Gebruik van eksperimentele metodes

- Uitvoering van eksperimente ten einde sekere basiese sielkundige en fisiologiese begrippe te demonstreer

KURSUS 2 - Toepassing van personeeltegnieke in die laboratorium, o.a. onderhoudvoering, opleidingstegnieke, ens.

KURSUS 3 - Toepassing en gebruik van sielkundige toetse

- Praktiese uitvoering van 'n kort navorsingsprojek uit een van die studieterreine.

Daar word so ver moontlik gepoog om van die personeel in die departement se praktiese ervaring gebruik te maak en sukses word behaal deurdat die studente besonder geesdriftig is om die praktiese uitvoering van beginsels te onderneem.

Die Departement onderneem ook navorsingsprojekte waaraan alle personeellede deel het. In die vroeëre jare is heelwat studies met betrekking tot motivering van die Swart werker uitgevoer, maar in die afgelope twee jaar het die klem verskuif na die psigometrika. Onder andere is 'n meganiese aanlegtoets vir hoëvlak Swart werkers opgestel en gestandaardiseer. Die konstruksie van 'n biografiese vraelys vir kleinhandel verkoopsdames is onlangs voltooi en tans word geldigheidstudies op die U.V.A.K.-klassifikasietoets uitgevoer. Finalejaar studente word tot 'n groot mate in hierdie navorsing betrek en hulle onderneem die invordering van data en doen meeste van die verwerking daarvan.

Nagraadse studente onderneem verder ook navorsing vir graaddoeleindes en tans is een magisterstudent besig met 'n studie om die omvang van die gebruik van Swart vroulike personeel in Suid-Afrika te ondersoek met die klem op vooroordeel teen hierdie werkersgroep.

Benewens die voorgenoemde poog hierdie Departement ook om alle senior studente ten minste een keer per jaar op 'n studie-reis te neem. Gewoonlik word fabrieke in die Oos-Kaap besoek ten einde beter kennis te maak met praktiese personeelprobleme, maar soms word inrigtings soos die Kamer van Mynwese se navorsingseenheid, die N.I.P.N. en ander 
instansies ook besoek. Sulke besoeke word gesien as 'n belangrike deel van die opleiding en afronding van Swart bedryfsielkundiges en dit blyk dat studente besondere belangstelling in hierdie reise het.

Die toekoms van die Departement Bedryfsielkunde aan die Universiteit van Fort Hare is rooskleurig. Nie alleen die bedryf nie, maar ook die studente besef dat Swart bedryfsielkundiges in die toekoms ' $n$ al hoe groter rol sal speel in die werksituasie in Suid-Afrika. Die beleid van hierdie Departement is dan ook om soveel moontlik studente te werf en indien die huidige studentegetalle konstant toeneem, kan verwag word dat hierdie Departement sal aanhou groei om in die toekoms een van die belangrikste sentra vir die opleiding van Swart bedryfsielkundiges te word. Die verskaffing van geriewe om studente toe te laat om as bedryfsielkundiges by die Mediese en Tandheelkunkundige Raad van Suid-Afrika te registreer, word tans onderneem. 